\title{
Dicephalus, Monostomus, Tetraopthalmus, Dipus, Dibrachius, Dicandatus monster in a Kankrej Cow
}

\author{
P M Chauhan*, H C Nakhashi, B N Suthar, V R Parmar ${ }^{1}$ \\ Department of Gynaecology and Obstetrics \\ College of Veterinary Science and Animal Husbandry \\ Sardarkrushinagar Dantiwada Agricultural University - 385506, Gujarat, India. \\ 1. Amul Dairy, Anand -388001, Gujarat, India. \\ * Corresponding author email: khanna vet@yahoo.co.in \\ Received: 30-07-2011, Accepted: 21-08-2011, Published Online: 17-11-2011 \\ doi: $10.5455 /$ vetworld.2012.38-39
}

\section{I ntroduction}

Congenital defect present at birth-the abnormality of structure or function and they may affect a single structure or function, an entire system, part of several systems or a structure and a function (Morrow, 1980). Duplication of cranial part of the fetus is more common than of the caudal parts (Roberts, 1971). These duplications may arise during the primitive streak elongation or regression (Noden and Lahunta, 1984). Monstroglia in bovine often leads to dystocia and caesarian section is the most common sequelae (Sharma, 2006). Here is the uncommon case of dicephalus, biatlanticus, monostomus, tetraopthalmus, dipus, dibrachis monster is reported.

\section{Case history and Clinical observation}

A full term Kankrej cow in third parity presented to Teaching veterinary clinic service complex, SDAU, Sardarkrushinagar with a history of labour pain since last 24 hours. Veterinary aid was provided by local veterinarian, but per vaginal delivery could not be facilitated.

The cow was alert with wet muzzle and good body condition. The rectal temperature was recorded to be $100^{\circ} \mathrm{F}$. Reddish and slightly fowl swelling discharge was noticed from vulva. Fetal forelimbs were protruded from vulva. Vulva was edematous and vaginal mucus membrane was dry and congested. Per vaginal examination revealed that the fetus was in anterior longitudinal presentation, dorso-iliac position. The head was found to be abnormal with two oral cavities and head impacted the vaginal canal. Eyeball was palpated. The ruptured of eye ball was due to the application of eye hook and traction. As the case was handled locally the vaginal mucus membrane was dry, inflamed and congested.

\section{Treatment and Discussion}

Considering the severity of the case and lack of space, the caesarean section was performed to deliver the fetus. The left lateral and parallel to milk vein site was prepared and a dead male monster fetus was delivered through the caesarean incision.

The monster had two heads (dicephalus), each head was having separate nostrils, two eyes (tetraopthalmus) and two ears. The heads had two atlas bone (biatlanticus) free from each other but fused at caudal part and continued with a single cervical vertebrae (Figure-I).

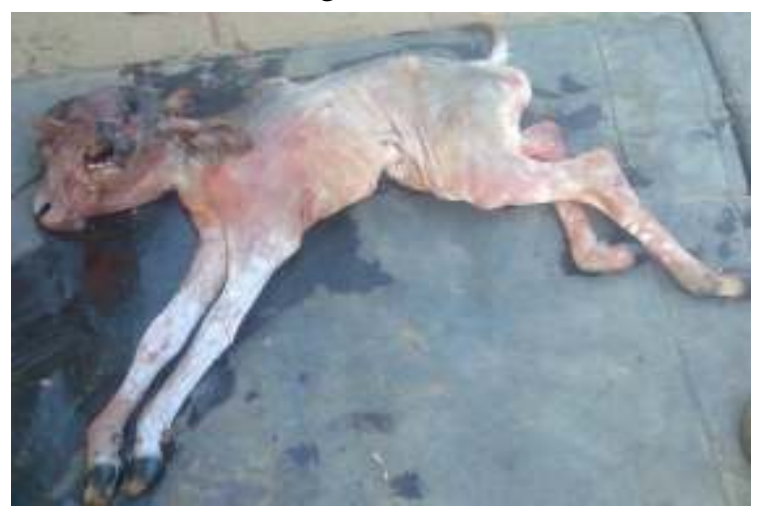

Figure - I. Dicephalus, biatlanticus, monostomus, tetraopthalmus, dipus, dibrachis monster 
Similar type of dicephalus biatlanticus monster has been reported in past by Raju et al., (2000). Chandrahasan et al., (2003) also reported similar monster which survived up to 45 minutes of delivery. Dystocia due to dicephalus monostomus in a crossbred cow has been also reported by Nakhashi et al (2006). In the present case the two heads were continued to a single neck leading to single thorax, two forelimb (dibrachius), two hind limbs and two tail (dicandatus).

However, only one scrotum with two testis was present. In postmortem examination of the fetus revealed that structure were duplicated upto pharynx where as there was only one oesophagus. All visceral organs e.g. lungs, heart, liver, kidneys, genitallia were of single fetus.

On the basis of gross examination the fetus was classified as dicephalus, monostomus, tetraopthalmus, dipus, dibrachius, dicandatus monster. Since the cow had delivered two normal calves in last two calving, the condition appears to be non hereditary origin and might have resulted due to abnormal duplication giving rise to fetuses whose body structures are partially but not completely duplicated (Potter, 1961).

\section{References}

1. Chanrahasan, C., Krishnakumar, K., Selvargan, M., Richard, P.V., Jagatheesan and Saravana kumar, V.R. (2003). Dysticia due to dicephalus monostomus monster in a crossbred cow. IJAR, $24(2): 175$.

2. Marrow A D (1980). Current therapy in theriogenology. W. B. Saunders company, London, PP925.

3. Nakhashi, H.C., Patel, P.B, Chaudhary, C.G., Faruquie, S., Pande, R and Chaudhary, S.R. (2006). Dystocia due to dicephalus monostomus in a crossbred cow. IJFV, (3), 49-50.

4. Noden, D.M. and Lahunta, A. D. (1984). The embryology of domestic animals developmental mechanisms and malformations; $1^{\text {st }}$ Edn. Williums and Wilkins Baltimore, London.

5. Potter, E.L. (1961). Pathology of foetus and infant. $2^{\text {nd }} \mathrm{Ed}$. Year book. Med. Publicers, Chicago.

6. Raju, K.G.S., Rao, K.S., Reddy, V.S.C. and Sharma, G.P. (2000) Dicephalus - biatlanticus monster in a buffalo. IJAR. 21(1): 81.

7. Roberts, S.J. (1971). Veterinary obstetrics and genital diseases, $2^{\text {nd }}$ Ed. C.B.S. Publicer and distributors, Delhi. PP70-73.

8. Sharma, A 2006. Caesarian section in animals under field conditions. A vectrospectine study of 50 cases. Ind. Vet . J. 83 (5): 544-45. 